\title{
Aspect Of Consumer Protection Against Circulation Of Hard Drug In The Market (Study At BPOM Medan)
}

\author{
Nova Liani Munthe
}

Sumatera University Faculty Of Law. E-mail: novamunthe12@gmail.com

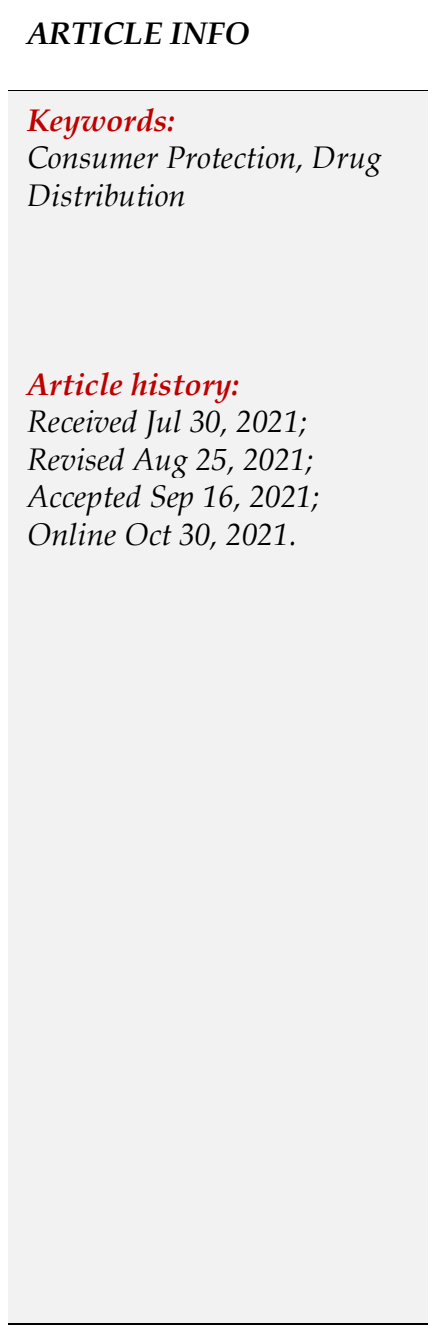

\begin{abstract}
Consumer protection is a matter of human interest, therefore it is a hope for nations in the world to be realized. Thus the importance of the issue of Consumer Protection in Indonesia, then issued a statutory regulation, namely Law no. 8 of 1999 concerning the Consumer Protection Act (known as UUPK). Especially Consumer Protection in the Health Sector which is something that is really needed by consumers in obtaining drug products circulating in the community, where the circulating drug products have been supervised by an agency that can be responsible for drug control. The Food and Drug Supervisory Agency (BPOM) is an agency appointed by the government in conducting drug control, The problems that will be discussed are first, how is the function of BPOM in Consumer Legal Protection. Second, how is consumer protection against the use of hard drugs. Third, what legal remedies can be taken by consumers as a result of losses in the use of strong drugs. The author obtains data and materials regarding the problems discussed, the author conducts Library Research, namely obtaining materials through reading sources or written materials as data of a scientific theoretical nature or secondary data. The author also conducts empirical research, namely obtaining data directly and conducting studies based on facts that occur in the field. Finally, conclusions were obtained, among others, first, the function of the Supervisory Board Drug and Food (BPOM) is to carry out control and supervision in the field of medicine and food. BPOM became aNon-Departmental Institution (LPND). Second, the role of the government is very necessary, namely by making a policy regarding food (food) which is carried out in an effort to control, supervise, develop and educate consumers and business actors. And invites consumers to think smart in consuming and using drugs, so that they are in accordance with the dose recommended by the doctor so they don't buy in any place. Third, legal remedies that can be taken by consumers are litigation or non-litigation, where non-litigation methods can be through the Dispute Resolution Agency (BPSK).
\end{abstract}

This is an open access article under the CC BY-NC license.

\section{Introduction}

Health is the most important thing needed by the human body. Efforts to improve the quality of human life in the health sector are very broad and comprehensive efforts, these efforts include improving public health, both physical and non-physical. In the National Health System it is stated that health concerns all aspects of life whose scope and reach are very broad and complex. In addition, the Indonesian people have a goal to build a complete human being, namely the fulfillment of all the needs of the Indonesian people, both physical and spiritual needs including health. To achieve that goal, all development activities carried out by this country must be transparent, and that transparency will spur everyone to compete in a healthy 
and strong manner and will provide so many challenges, According to Law no. 36 of 2009 concerning Health, hereinafter referred to as the Health Law, the definition of health is a state of health, both physically, mentally, spiritually and socially that enables everyone to live socially and economically productive lives. While the definition of health according to Wikipedia is a state of well-being of body, soul and social that allows everyone to live productively socially and economically. WHO also defines health as a state of physical, mental and social well-being and not merely the absence of disease or infirmity.

Health is a human right, according to the development of international human rights law, fulfilling the need for the right to health which is the responsibility of the government in every country. Therefore, the government of each country is obliged to provide health rights to its people as described in Article 14-20 of Law no. 36 of 2009 concerning Health. This is because health is one indicator of the level of human welfare so that it becomes a priority in the national development of a nation. One of the most important health components is the availability of drugs as part of public health services. This is because drugs are used to save lives, restore or maintain health.

In health services, drugs are an important component because they are needed in most health efforts. Nowadays, increasing public awareness and knowledge about health also encourages people to demand health services, including drug services that are increasingly qualified and professional. It is hoped that more independent research and development activities will continue to be increased to produce local medicines that are cheaper and available to all groups.

The supply of medicines from imports is high because in fact the government's treatment of drugs is almost the same as for luxury goods with a $10 \%$ value added tax, import duty and $5 \%$ tariff. This makes medicines very expensive when the poor need them. In addition to price, another problem is the relatively limited availability of drugs. Indeed, being healthy and staying healthy is our common hope. However, this expectation does not always match reality.

Various high activities along with a lifestyle that tends to like instant things, for example consuming fast food, and various pollutions of air, soil, water and sound trigger our health decline. When you are in an unhealthy condition there is no other choice but to take treatment. Unfortunately, various types of treatment are not always curative, in fact it is not uncommon when using inappropriate drugs will actually cause new diseases. Because of the above and because of the very important function of the drug, many people abuse it. One example is that many people deliberately distribute drugs without obtaining permission from the Head of BPOM. Because drugs without a permit from the Head of BPOM are easy to obtain and the price is much more economical than legal drugs that have received distribution permits from the Head of BPOM. The profit obtained by the seller is also not small. This lucrative profit is what makes more and more people interested in selling illegal drugs whose composition can have a hard impact and are not registered with BPOM. People who don't even know are the victims. Even though it is not certain that the drug being circulated is correct and has the right composition. By being falsified, medical costs can be reduced because the active ingredients can be reduced or not in the right amount. Obviously this is very dangerous for patients or users of certain brands of drugs. The profit obtained by the seller is also not small. This lucrative profit has made more and more people interested in becoming sellers of illegal drugs whose composition can have a hard impact and are not registered with BPOM. People who don't even know are the victims. Even though it is not certain that the drug being circulated is correct and has the right composition. By being falsified, medical costs can be reduced because the active ingredients can be reduced or not in the right amount. Obviously this is very dangerous for patients or users of certain brands of drugs. The profit obtained by the seller is also not small. This lucrative profit is what makes more and more people interested in selling illegal drugs whose composition can have a hard impact and are not registered with BPOM. People who 
don't even know are the victims. Even though it is not certain that the drug being circulated is correct and has the right composition. By being falsified, medical costs can be reduced because the active ingredients can be reduced or not in the right amount. Obviously this is very dangerous for patients or users of certain brands of drugs. People who don't even know are the victims. Even though it is not certain that the drug being circulated is correct and has the right composition. By being falsified, medical costs can be reduced because the active ingredients can be reduced or not in the right amount. Obviously this is very dangerous for patients or users of certain brands of drugs. People who don't even know are the victims. Even though it is not certain that the drug being circulated is correct and has the right composition. By being falsified, medical costs can be reduced because the active ingredients can be reduced or not in the right amount. Obviously this is very dangerous for patients or users of certain brands of drugs.

To ensure the correct and correct composition of drugs, the pharmaceutical industry must carry out all aspects of the series of production activities by applying Good Manufacturing Practices (CPOB) and Good Traditional Medicine Manufacturing Methods (СРОТВ). CPOB and СРОТВ are guidelines made to ensure that the nature and quality of the drug produced is in accordance with the requirements that the prescribed drug quality standard is achieved.

Nowadays, there is rampant circulation of illegal drugs, one of which is the circulation of drugs that have not received distribution permits and have a strong effect. The rampant circulation of illegal drugs in Indonesia proves that Indonesia's defense is still weak from the invasion of things that endanger the community. Allowing the circulation of illegal drugs or not registered with BPOM is tantamount to allowing the public to face various bad risks, allowing crime to develop in society, and degrading the trust, dignity, and self-esteem of the nation in the eyes of the international community.

Consumer protection is a matter of human interest, therefore it is a hope for all nations in the world to be able to make it happen. Realizing consumer protection is to create a relationship between various elements with one another, namely between consumers, entrepreneurs and the government because all three are related and interdependent in improving the quality and quantity of health in the community.

\section{Method}

The writing of this thesis was carried out by the author using normative legal research, namely researching using library materials or secondary data. Writing this thesis uses two data collection techniques, namely research through the library (library research) and field research (field research). Literature research is carried out by collecting data related to this thesis which can be used as a basis for research and analyzing existing problems. Field research is carried out by going directly to the field. Data collection was carried out by direct interviews with respondents, namely the Head of Certification and Consumer Services of the Food and Drug Supervisory Agency (BPOM), Mrs. Neni and the Administrative Section of BPOM, namely Mrs. Panggabean.

In the preparation of this thesis, the data obtained will be analyzed using qualitative methods which produce descriptive analytical data, namely what is stated by the respondent orally, described and then analyzed.

\section{Analysis And Results}

\subsection{Aspects Of Consumer Protection Against Circulation Of Hard Drugs In The Market}

a. Criteria for Drugs that Can be Registered at BPOM 
Drugs are preparations or combinations of materials that are ready to be used to influence or investigate physiological systems or pathological conditions in the context of establishing diagnosis, prevention, healing, recovery, improvement, health and contraception (National Drug Policy, 2005). According to Ansel (1985) "Drugs are substances used to diagnose, reduce pain, and treat or prevent disease in humans or animals". Meanwhile, according to the Decree of the Minister of Health No. 25/Kab/B.VII/71 dated June 9, 1971, what is called a drug is a substance or a combination of ingredients to be used in establishing a diagnosis, preventing, reducing, eliminating, curing diseases, injuries or physical and spiritual disorders in humans or animals, beautify the body or human body parts.

However, for a doctor, this knowledge is limited in purpose, namely to be able to use medicine for the purpose of prevention, diagnosis, and treatment of disease. In addition, to understand that the use of drugs can cause various symptoms of disease (Pharmacology Section, Faculty of Medicine, University of Indonesia). Drugs are objects that can be used to treat disease, relieve symptoms, or modify chemical processes in the body.

Drugs are chemical compounds other than food that can affect living organisms, the use of which can be to diagnose, cure, prevent a disease. Medicine is one of the components that cannot be replaced in health services. Drugs are different from trading commodities, because apart from being a trading commodity, drugs also have a social function. Drugs play a very important role in health services because the treatment and prevention of various diseases cannot be separated from therapeutic actions with drugs or pharmacotherapy. As stated in the definition of drugs above, the role of drugs in general is as follows:

1) Diagnosis

2) For disease prevention

3) Cure disease

4) Restore (rehabilitate) health

5) Altering the normal functioning of the body for a specific purpose

6) Health improvement

7) Reduce pain.

The rapid progress of science and technology has encouraged the development of drugs, including ingredients, quality improvement, safety, discovery of new indications and formulations. That the public also needs to increase their knowledge about drugs, also follow the current rapid development of drugs and know the criteria for drugs that are suitable for consumption. So that people can know how to distinguish which drugs are suitable for consumption and which are not suitable for consumption.

Before being used by patients or the public, drugs undergo various long processes, starting from the provision of raw materials, manufacturing processes, packaging processes, packing, shipping, storage and distribution. Each process certainly poses a risk of contamination to the quality of the drug. For example, when raw materials are processed into finished drugs and made in certain dosage forms, this entire process must ensure that there are no contaminants, the drug will not change its shape, color, smell, taste and consistency, and remain stable in its dosage form during the entire process. finished. Therefore, in the factory, CPOB is known (Good Method of Making Medicines), to ensure that drugs that have gone through the manufacturing process have been tested for quality, both in terms of content, preparation, stability, to their potency. Likewise, the next process, namely packaging, labeling, packing, shipping, storage and distribution must ensure that the drug remains in its original dosage form without undergoing physical or chemical changes that can affect the clinical effect of the drug when used. For example, a drug in the form of a dry syrup does not require packaging and storage that is free from moisture. This is to ensure the dry syrup form does not change when used by the patient. Therefore, certain criteria are needed for packaging and storage. storage and distribution that must ensure that the drug remains in its original dosage form 
without undergoing physical or chemical changes that can affect the clinical effect of the drug when used. For example, a drug in the form of a dry syrup does not require packaging and storage that is free from moisture. This is to ensure the dry syrup form does not change when used by the patient. Therefore, certain criteria are needed for packaging and storage. storage and distribution that must ensure that the drug remains in its original dosage form without undergoing physical or chemical changes that can affect the clinical effect of the drug when used. For example, a drug in the form of a dry syrup does not require packaging and storage that is free from moisture. This is to ensure the dry syrup form does not change when used by the patient. Therefore, certain criteria are needed for packaging and storage.

\section{b. Functions of BPOM in Consumer Legal Protection}

Many people do not know about the function of the Food and Drug Supervisory Agency, even though with so many consumer goods circulating in the market, people really need clearer information and guarantees about the safety of the goods they buy. Moreover, many of these goods are products originating from outside Indonesia and their safety cannot be guaranteed. Therefore, the Indonesian people need to know about the function of the Food and Drug Supervisory Agency.

Based on Presidential Decree No. 166 of 2003, as amended by Presidential Decree no. 103 of 2000 concerning the Position, Duties, Functions, Authorities, Organizational Structure and Work Procedures of Non-Departmental Government Institutions, the Drug and Food Control Agency (Balai POM) is designated as a Non-Departmental Government Institution (LPND) responsible to the President.

Function The Food and Drug Supervisory Agency (BPOM) is to carry out control and supervision in the drug and food sector. BPOM became a Non-Departmental Institution (LPND). Therefore, as a democratic country, Indonesia must have an agency that takes care of in the health and pharmaceutical sectors as well as supervising the drug and food sectors. The authority and function of BPOM to carry out its duties, like developing countries, are handled by the government to agencies that according to law can implement them to support overall economic growth.

The Food and Drug Supervisory Agency (BPOM) as an LPND has the function and authority in establishing regulations in the field of medicine and food, both in the form of laws and hierarchical provisions under it to be effective, clearly requiring human resources capable of carrying out orders. and carry out law enforcement or the provisions of these laws and regulations. As stipulated in the provisions of Article 67 of Presidential Decree Number 103 of 2001, the functions of BPOM are as follows:

1) Reviewing and formulating national policies in the field of drug and food control

2) Implementation of certain policies in the field of drug and food control

3) Coordination of functional activities in the implementation of BPOM tasks

4) Monitoring the provision of guidance and guidance to the activities of government agencies and the public in the field of drug and food control

5) Implementation of coaching and administrative services in the fields of general planning, administration, organization, and management, personnel, finance, archives, law, supplies, equipment and household.

As a government agency that has the task of carrying out the supervisory function in the field of medicine and food, all programs and activities of BPOM have an essential objective, namely to protect the public as consumers on the quality, safety, and benefits of circulating medicinal and food products.

The functions of the Food and Drug Supervisory Agency (BPOM) are as follows: 
1) Regulation, regulation and standardization

2) Industrial licenses and certifications in the pharmaceutical field based on good production methods

3) Product evaluation before it is allowed to circulate

4) Post marketing vigilance including sampling and laboratory inspection, inspection of production facilities and distribution facilities, providing and enforcing laws

5) Pre-audit and post-audit of advertising and production

6) Research on the implementation of drug and food control policies

7) Public communication, information and education including public warnings.

The Food and Drug Supervisory Agency has a technical implementing unit domiciled in the region under the name Balai Besar POM. The position, duties and functions of Balai Besar POM are regulated based on the Decree of the Head of the Indonesian Food and Drug Supervisory Agency No. 05018/SK/KBPOM dated May 17, 2001 are as follows: The Technical Implementation Unit within the Food and Drug Supervisory Agency, especially in Medan, has the task of implementing policies in the field of supervision of therapeutic products, narcotics, psychotropics and other addictive substances, traditional medicines, cosmetics, pharmaceutical products. complement, food safety and hazardous materials.

\section{c. Consumer Protection Against the Use of Strong Drugs}

Talking about medicine means talking about all substances, both chemical, animal and vegetable, which in appropriate doses can cure, relieve or prevent disease and its symptoms. Most of the drugs used in the past were drugs derived from plants. By trial and error, ancient people empirically gained experience with various kinds of leaves or plant roots to cure diseases. This knowledge has been stored and developed from generation to generation, so that the science of folk medicine appears, as is traditional medicine in Indonesia.

Drugs that fall into this group of hard drugs are drugs that are packaged in such a way that are used parenterally, either by injection or by other means of use by tearing the tissue, new drugs that have not been listed in the latest compendial/pharmacopoeia applicable in Indonesia and drugs -drugs designated asai hard medicine through the decision of the Minister of Health of the Republic of Indonesia. Complete information is needed regarding the use of this drug because if it is not used properly it can cause side effects that are not good for the bodyPharmacist if you get drugs labeled hard drugs from a doctor's prescription, the use of the right drugs will increase the effectiveness of the drug against the disease and minimize side effects.

These dangerous drugs can only be dispensed through pharmacies by law, but in practice they can often be purchased at many drugstores. This is very concerning because then its use can no longer be properly monitored so that it can pose a danger to the user. Included in the Decree of the Minister of Health which was issued on July 16, 1990. This list stipulates hard drugs that can be purchased at pharmacies without a doctor's prescription in limited quantities and potencies. Patients are required to provide their address, which is registered by the pharmacist along with the name of the drug being given. The list includes, among others: anti-pregnancy pills, triamcinolone thrush ointment, acetylcysteine phlegm dissolving drug, pain medication mafenamic acid (also in combination with diazepam), all antihistamines and the anthelmintic mabendazole. In addition, the list also includes a number of strong drugs in ointments or creams, namely antibiotics, several anti-inflammatory hormones, the numbing agent lidocaine, the antifungal agent miconazole and nystatin. All ointments or creams are defined in terms of packaging and quantity.

In its use, drugs have various forms. All forms of medicine have their own characteristics and purposes. There are substances that are not stable if they are in tablet preparations so that they must be in capsule form or there are also drugs that are intended to dissolve in the intestines 
not in the stomach. All are specially formulated to achieve the desired therapeutic effect and drug ethics should contain brief but correct and clear instructions. Therefore, consumers or passions must be wise and smart in choosing, buying and using these drugs according to the existing recommendations, especially with the use of hard drugs, the dosage and purchase must be carefully monitored using a doctor's prescription, so that there will be no errors that result in later. fatal to the patient himself.

Drug Standards according to BPOM:

1) There must be a dose and according to the doctor's prescription, beside there must be a red "K" symbol with a black border.

2) Should not be sold freely and sold in drug stores.

3) Must obtain registration permission from BPOM.

\section{d. Legal Efforts Consumers Can Take Due to Losses in the Use of Strong Drugs}

Consumer disputes are disputes regarding violations of consumer rights. In terms of consumer dispute resolution, in some countries a special agency/or institution is generally formed, such as in the UK, Hong Kong, and Sweden, an institution known as the "Small Claim Court" (Small Consumer Court), in the Netherlands the judicial institution is known as the "Small Claim Court". Chillen Commissie" (Small Consumer Settlement Commission). In Indonesia, in accordance with applicable laws, consumer settlements can be pursued through the courts, for example general courts or out of court based on the voluntary choice of the disputing parties. So the parties can choose to voluntarily settle their consumer disputes, either through court or out of court. In connection with this consumer dispute resolution, explanation of Article 45 paragraph (2) of Law no. 8 of 1999 states: "The settlement of consumer disputes as referred to in this paragraph does not rule out the possibility of an amicable settlement by the disputing parties. At each stage, efforts are made to use an amicable settlement by both parties to the dispute. What is meant by a settlement carried out by both parties to the dispute (business actors and consumers) without going through a court or the Consumer Dispute Settlement Agency and not contradicting this law".

Thus, based on the provisions of Article 45 paragraph (2) of the Law, No. 8 of 1999 is related to the explanation, so that efforts to protect consumers as end users of a product or service require various legal aspects to be truly protected and fair. ${ }^{66}$ So it can be concluded that consumer dispute resolution can be done in the following ways:

\section{1) Dispute Resolution through the Court}

The authority to settle consumer disputes through the courts is in the hands of the courts within the general court environment by referring to the provisions applicable in that environment. Parties who can file lawsuits for violations of business actors through the courts according to Article 46 of Law no. 8 of 1999 includes:

a) A consumer who is harmed or the heir concerned. A group of consumers who have the same interests.

b) A non-governmental consumer protection institution that meets the requirements is in the form of a legal entity or foundation, which in its articles of association clearly states that the purpose of establishing the organization is for the benefit of consumer protection and carrying out activities in accordance with its articles of association.

c) The government and/or related agencies if the goods and/or services consumed or utilized result in large material losses and/or no small number of victims. To accommodate the powers conferred by law Consumer protection for BPSK as the institution tasked with resolving consumer disputes out of court, UUPK authorizes BPSK to impose administrative sanctions for business actors who violate certain prohibitions imposed on perpetrators. Efforts in the Consumer Dispute Settlement Law as referred to in Article 45 paragraph (2) of this UUPK do not cover the possibility of an 
amicable settlement by the disputing parties, at every stage endeavors to use a peaceful settlement by both parties to the dispute. What is meant by amicable settlement is a settlement carried out by both parties to the dispute (business actors and consumers) without going through a court or BPSK. But at this time will be discussed about BPSK. According to Article 52 of UUPK, BPSK has the following powers:

d) Carry out handling and settlement of consumer disputes by means of mediation or arbitration or conciliation;

e) Provide consumer protection consulting;

f) Supervise the inclusion of standard clauses;

g) Reporting to the general investigator if there is a violation of the provisions of this law;

h) Receive written and unwritten complaints from consumers regarding violations of consumer protection;

i) Conduct research and examination of consumer protection disputes;

j) Calling business actors suspected of having violated the consumer protection;

k) Summon and present witnesses, expert witnesses and/or any person who is deemed to know the violation of this law;

1) Request assistance from investigators to present business actors, witnesses, expert witnesses, or any person as referred to in letters $g$ and $h$, who are not willing to comply with the summons of the consumer dispute settlement agency;

m) Obtain, examine and/or evaluate letters, documents, or other evidence for investigation and/or examination;

n) Decide and determine whether or not there is a loss on the part of the consumer;

o) Notify the decision to business actors who commit violations to consumer protection;

p) Imposing administrative sanctions on business actors who violate the provisions.

The number of complaints cases recorded shows that the rights of consumers in Indonesia are not sufficient for the rights that must be received by consumers contained in the consumer protection law. One of the reasons for the increase in complaints recorded by YLKI is the number of consumers who complain about their dissatisfaction with the goods/services used to business actors, but consumers must follow a long procedure to get service satisfaction for consumers. Whereas according to article 5 of the Consumer Protection Law paragraph 7 "The right to be treated or served correctly and honestly and not discriminatory". In fact, consumers have not yet received what is contained in the article. And often consumer complaints are ignored by business actors which trigger consumers to report to YLKI.

\section{Conclusion}

Regarding consumer protection in the distribution of hard drugs that are not registered in the market, the public is strongly advised to pay attention to everything before consuming the drug. Both in terms of safety, quality, medicinal ingredients, how to use it, namely in accordance with a predetermined dose, not sold freely, registered and must use a doctor's prescription. The obligations and responsibilities of producers are also set forth in the Consumer Protection Act and all provisions governing the business activities of selling drugs in force in the Republic of Indonesia.

Given the relatively weak position of consumers compared to producers, consumers have the right to obtain legal protection for losses from within, where legal protection to food consumers is directed to achieve the following objectives: (1) Creating a consumer protection system that contains information disclosure and guarantees legal certainty. (2) Protect consumers in particular and all producers. (3) Improving the quality of food circulating in the community, so that people can consume the food. (4) Provide legal protection to consumers from producer practices that harm consumers through fraud against the food products they produce.

The role of the government is very much needed to provide protection to consumers for drugs 
circulating in the market. By making a national drug policy, this is carried out in an effort to control and supervise as well as guidance and counseling, including also in terms of providing information through promotions so as not to mislead drug users., inspection of distribution product facilities, investigation, and law enforcement, so that the government also conducts supervision, communication, information and education through the relevant agencies.

Legal protection as a result of the use of hard drugs in circulation in the market that causes harm to consumers. So consumers can ask for compensation to the drug manufacturer through legal remedies, namely legal remedies in litigation (court) or out of court. Meanwhile, legal remedies outside the court can be done through the Consumer Dispute Settlement Agency (BPSK).

\section{References}

NC, Agnes. 2013. The Art of Healthy Living Without Doctors. Yogyakarta: Chivita Books.

Kristiyanti, Celine Tri Siwi. 2011. Consumer Protection Law. Jakarta: Sinar Graphic.

Miru, Ahmadi \& Sutarman Yodo. 2008. Protection Law Consumer. Jakarta: Raja Grafindo Persada.

R. Saliman, Abdul. 2005. Business Law For Companies. Jakarta: Pranada Media Group.

Santoso, Mas Ahmad. 1997. Concept and Application of Representative Lawsuit (Class Action). Jakarta: Environmental Law Development Institute.

Shidarta. 2000. consumer protection law. Jakarta : Grasindo.

Sophie, Yusuf. 2000. Consumer Protection and Legal Instruments. Bandung: PT Citra Aditya Bakti.

Sidabalok, Janus. 2010. Consumer Protection Law. Bandung: Image of Aditya Bakti.

Sirait, Midian. 2001. Three Dimensions of Pharmacy. Jakarta: Darma Mahardika Agency. Susanto, Happy. 2008. Consumers' Rights If Aggrieved. Jakarta: Transmedia References.

Syawali, Husni \& Neni Imaniyati,. 2000. Law Consumer protection. Bandung: Forward Mandar.

Widjaja, Gunawan and Ahmad Yani. 2003. Law on Consumer Protection. Jakarta: PT Gramedia Pustaka Utama.

Widjaja, Gunawan. 2001. Alternative Dispute Resolution. Jakarta: PT Raja Grafindo Persada.

Zulham. 2013. Consumer protection law. Jakarta : Prenada Media Group.

Law Number 8 of 1999 concerning Consumer Protection, Article 1 paragraph 2.

Law No. 8 of 1999, Article 64.

Law Number 10 of 1961 concerning Stipulation of Government Regulation in Lieu of Law Number 1 of 1961 concerning Goods Becomes Law.

Law Number 14 of 1992 concerning Road Traffic and Transportation Law Number 23 of 1992 concerning Health.

Law Number 5 of 1999 concerning Prohibition of Monopolistic Practices and Unfair Business Competition, Article 1.

Regulation of the Head of the Food and Drug Supervisory Agency Criteria and Procedure for Withdrawal of Drugs Not Meeting the Standards and/or Requirements in 2011. 
St. Drugs Act. No. 419 date. 22 December 1949 and based on Health Law No. 23 of 1992 Law No. 8 of 1999, Article 1 paragraph 1 “Definition of Consumer Protection.

Law No. 8 of 1999, Article 52.

http://adln.lib.unair.ac.id/go.php?id=gdlhub-gdl-s1-2008-faisalboy-7614

http://asejuk.wordpress.com/2011/09/09/obat-is/accessed on September 30, 2013.

http://seksikefarmasianumenep.blogspot.com/2013/02/kebijakan-obat-national.htmlaccessed October 01, 2013.

http://asejuk.wordpress.com/2011/09/09/obat-is/accessed on October 17, 2013.

http://www2.pom.go.id/public/ Hukum_perundang/pdf/per_09938(2).pdf accessed on October 17, 2013.

http://www.pom.go.id/ accessed on 19 September 2013.

http://farmasi-istn.blogspot.com/2008/01/pengertian-obat.html accessed on October 21, 2013.

http://kesehatan Keluarga.net/articles/side-effect-obat-free-Hard.html accessed on October 21, 2013. 